\title{
Harran Ovası Tarımsal İşletmelerinde Risk Analizi
}

\author{
Ali Rıza $\mathrm{MANCl}^{1 *}$, Mehmet Emre EREN ${ }^{2}$ \\ ${ }^{1}$ Harran Üniversitesi, Turizm ve Otel İşletmeciliği Yüksekokulu, Şanlıurfa, Türkiye \\ [ORCID: http://orcid.org/0000-0003-4618-5891] \\ ${ }^{2}$ Harran Üniversitesi, Teknik Bilimler MYO, Şanlıurfa, Türkiye \\ [ORCID: orcid.org/0000-0003-1851-0765] \\ 'Sorumlu yazar: armanci@harran.edu.tr
}

Öz

Tarımın insan beslenmesi, yoğun iş gücü kullanarak istihdam yaratması, sanayi sektörüne girdi temin etmesi bakımından önemi tartışmasızdır. Fakat tarımsal üretimin sanayi üretimi ile kıyaslandığında, evrensel kabul görmüş farklı özelliklere sahip olduğu bilinmektedir. Üreticiler, birçok risk ve belirsizlikle karşı karşıya bulunmaktadırlar. Bölgelerarası değişmekle birlikte, tarım sektörünün en çok karşılaştığı riskler: piyasa riski (fiyat dalgalanmaları), ülkedeki ekonomik durum, girdi maliyetlerindeki değişiklik, ürünün pazarlama zorluğu, ürünün satış zamanı, arazi fiyatlarındaki değişiklik, ürünlerin depolanabilirlik durumu, ürünlerin verimindeki değişiklikler, felaket (don, kuraklık, sel, erozyon, yangın vb) riskleri, kredi ve likidite riski, sermaye yapısı ve teknolojik yetersizlikleridir. Bu çalışmanın amacı; Harran Ovasında sulu koşullarda üretim yapan tarımsal işletmelerin karşılaştıkları riskleri tespit etmek ve riske karşı olan tutumlarını belirlemektir. Bu maksatla, kolayda örnekleme yöntemiyle belirlenen 140 üretici ile yüz yüze anket uygulanmış ve istatistiki açıdan uygun yöntemler kullanılarak analiz edilmiştir. Sonuç olarak, en çok karşılaşılan risklerin; hastalık ve zararlılar, iklim koşulları ve fiyatların istikrarsız oluşları olduğu tespit edilmiştir. Eğitim düzeyinin, medeni halin, daha önce tarım sigortası yaptırıp yaptırmama değişkeninin, kredi kullanma durumunun ve devletin tarım sigortası için prim desteğinin üreticilerin tarım sigortası yaptırma kararında etkili olduğu saptanmıştır.

Anahtar Kelimeler: Tarımsal risk, Sigorta, Belirsizlik, Harran ovası, Şanlıurfa

\section{Risk Analysis of Agricultural Business in Harran Plain}

\begin{abstract}
Agriculture is indisputably important for Human nutrition, creation of employment using labor intensive technique, and to provide input to the industrial sector. But agricultural productions have universally accepted different characteristics when comparing with industrial sector. Agricultural producers with whom are faced with many risks and uncertainties. The agricultural sector are faced with many risks which vary between regions: market risk (price volatility), the economic situation in the country, changes in input costs, marketing difficulties, product sales time, changes in land prices, storability status of products and changes in the yield of products, disaster (frost, drought, floods, erosion, fire, etc.) risk, credit and liquidity risk, structure of capital and risks of technological insufficiency. This study aims to identify risks faced by agricultural enterprises engaged in production under irrigated conditions in the Harran Plain and to determine attitudes towards risk. For this purpose, face-to-face surveys were conducted with 140 producers identified with conveinence sampling method and the appropriate statistics methods were analyzed. As a result, the professional experience, level of education, marital status, before agriculture cover and still make my variable of the credit use, and the government's agricultural primary support for insurance producers were found to be effective in the decision to agriculture insurance. The most common risks, diseases and pests, climatic conditions unstable prices were observed.
\end{abstract}

Key Words: Agricultural risk, Insurance, Uncertainity, Harran Plain, Sanliurfa 
Giriş

Tarım, toprağı ve tohumu kullanarak bitkisel ve hayvansal üretim faaliyetinde bulunmak olarak tanımlanmaktadır. Tarımın insan beslenmesi, yoğun işgücü kullanarak istihdam yaratması, sanayi sektörüne girdi temin etmesi bakımından önemi tartışmasızdır. Fakat tarımsal üretimin sanayi üretimi ile kıyaslandığında, evrensel kabul görmüş farklı özelliklere sahip olduğu bilinmektedir.

Tarım sektörünün farklı özelliklerini; tabiat şartlarının hâkim olması, üretimin mevsimsel oluşundan dolayı arz esnekliğinin düşük olması, azalan verimler kanununun geçerli olması, kısa dönemde arz talep denkliğinin sağlanamaması, talep ve gelir esnekliğinin az olması, üreticilerin eğitiminin düşük olması, risk ve belirsizliğin çok yüksek olması (İnan, 2016) sebebiyle, üreticilerin gelirlerinde dalgalanmaların (Akçaöz ve ark., 2006) yaşanması şeklinde sıralayabiliriz.

Bunlar arasında risk ve belirsizliğin çokluğu öne çıkmaktadır. Keza, risk, belirsizlik ve risk yönetimi yani üreticilerin risk davranışları; güncel literatürdeki temel kavramlardandır. Risk aslında baştan hesaplanabilen, olası, ortadan kaldırılması için çeşitli önlemler alınabilen beklenen bir zarardır. Genel olarak işletmelerin karşılaştıkları riskleri finansal, operasyonel, stratejik ve dış çevre riskleri (Özcan, 2012) olmak üzere dört temel başlık altında toplamak mümkündür.

Belirsizlik ise hesaplanamayan, beklenmeyen bir durumu yansıtan, önceden görülemeyen ve tedbir alınamayan ve olası olmayan bir kayıp ile karşılaşılmasıdır. Bu açıdan bakıldığında, belirsizliği ve belirsizliğin getireceği sorunları ciddi tehlike (tuzlaşma, çoraklaşma, verim vb.) ve kayıplar oluşturmadan, kabul edilebilir bir seviyeye indirmek ancak risk yönetimi ile mümkündür. Risk yönetimi ise, kurumların hedeflerine ulaşmasını engelleyici risklerin ve hedeflere ulaşımı kolaylaştırıcı fırsatların önceden fark edilerek yönetilmesini sağlayan dinamik ve disiplinli bir sistem olarak tanımlanmaktadır (Kızılboğa, 2012).

Bölgelerarası değişmekle birlikte tarım sektörünün en çok karşılaştığı riskler; piyasa riski (fiyat dalgalanmaları), ülkedeki ekonomik durum, girdi maliyetlerindeki değişiklik, ürünün pazarlama zorluğu, ürünün satış zamanı, arazi fiyatlarındaki değişiklik, ürünlerin depolanabilirlik durumu, ürünlerin verimindeki değişiklikler (Şahin ve ark. 2008), felaket (don, kuraklık, sel, erozyon, yangın vb.) riskleri, kredi ve likidite riski, sermaye yapısı ve teknolojik yetersizlik riskleri olarak varsayılmaktadır (Özcan, 2012).

Son yıllarda tarım ekonomisi literatüründe bu çeşit ve benzeri türden risklerin ortadan kaldırılması için gerek ulusal gerekse uluslararası alanda çalışmalar yapılmış; çeşitli çözüm önerileri sunulmaya çalışıımıştır (Pennings and Garcia, 2001; Akçaöz ve ark., 2006; Şahin ve Miran, 2007; Şahin, ve ark., 2008; İpekçioğlu ve ark., 2010; Çetin ve Esengün, 2012; Çetin ve Esengün, 2013; İkikat ve Birinci, 2013; Bergfjord, 2013; Keskinkılıç 
ve Alemdar, 2013; Kopali and Doko, 2014; Aydoğdu ve Yenigün, 2016). Ancak, Harran Ovası ile ilgili çalışmalar kısıtlı sayıdadır. Örneğin; Aydoğdu (2016), Harran Ovası'nda kuru ziraat yapan üreticilerin risk algıları ve bunu etkileyen faktörleri ödeme istekliliği yöntemi kullanılarak incelenmiş, çiftçilerin \% 57'sinin sürdürülebilir çevre için gelirlerinden bir miktar ödemeye razı oldukları bulgusuna ulaşmıştır.

1995 yılında Harran Ovasının sulamaya açılmasıyla birlikte sulanan arazi miktarı artmış buna paralel olarak yoğun teknoloji ve girdi kullanımı üst seviyelere çıkmıştır (Çetin ve Esengün, 2012). Bu nedenden dolayı, üreticiler çeşitli riskler ile karşı karşıya kalmışlardır. Tarımsal işletmelerde, risk faktörlerini en aza indirmek için çok çeşitli tedbirler alınabileceği öngörülmektedir. Üretim riskini asgariye indirmek açısından, ürün çeşitlendirmesi, fazladan üretim gücü, kayıt sistemi, hastalık ve zararlılarla etkin mücadele ve sigorta tavsiye edilebilir. Pazarlama riskine karşı, hedging vadeli satış, depolama, ürünün tüketiciye doğrudan arz edilmesi sıralanabilir. Elde daha fazla nakit tutma, borçlanmayı azaltma ve maliyetini düşürme mali riskleri en aza indirmek için kullanılabilecek araçlardır. Çok çeşitli risklerle karsı karsıya kalan üreticilerin aldıkları veya almayı düşündükleri tedbirlerin ortaya çıkarılması, konuyla ilgili kişilere, kurumlara ve şirketlere bir ışık tutabileceği öngörülmektedir.

Harran Ovası yaklaşık 1300000 ton ile Türkiye'de yetiştirilen pamuğun
\% 42'lik bir kısmını üretmektedir. Bu sebeple, çalışma alanı ovada sulu koşullarda üretim yapan tarımsal işletmeler seçilerek sınırlandırılmıştır. Böylece, Harran Ovası'nda bulunan tarımsal işletmelerin sosyo-ekonomik özelliklerinin yanında, karşılaştıkları riskler ve bu risklerin üstesinden gelmek için tercih ettikleri risk davranışlarını belirlemeye çalışmak bu çalışmanın amacını oluşturmaktadır.

\section{Materyal ve Metot}

Harran Ovasında sulu koşullarda üretim yapan tarım işletmeleri araştırmanın evrenini oluşturmaktadır. Şanlıurfa Tarım il müdürlüğü ÇKS'ye (Çiftçi Kayıt Sistemi) göre bu tarzda üretim yapanların sayısı 12837 olarak belirlenmiştir. Buna göre, kolayda örnekleme yöntemi kullanılarak üreticilerle yüz yüze anket uygulaması gerçekleştirilmiştir. Örneklem sayısı, tarım ekonomisi literatüründe kullanılan aşağıdaki formül yardımıyla hesaplanmıştır (Yamane, 2010);

$$
n=\frac{N t^{2} p q}{d^{2}(N-1)+t^{2} p q}
$$

$\mathrm{n}$ : Örneklem hacmini, N: Ana kitledeki birim sayısını, ana kitledeki birim sayısı Örneklem büyüklüğü 30'dan fazla olduğu için z değeri alınmıştır. Z tablo değeri \% 98 güven aralığında 2.33 olarak alınmıştır. $p$ ve $q$ anket sayısını arttırmak için olasılık değerleri 0.50 olarak formüle dahil edilmiştir. \% 10 hata payı ile çalışıldığından, d değeri 0.1 olarak alınmıştır. 
Yukarıdaki formülde değerler yerine konulduğunda 134 adet anket yapılmasının çalışmadan sağlıklı sonuçlar elde edilmesi açısından uygun olacağı sonucuna varılmıştır.

Sahada uygulanan anketlerden elde edilen verilerin uygun analiz yöntemleri ile değerlendirilebilmesi için, veri tabanı oluşturulmuş ve anket verileri bu veri tabanına girilmiştir. Örneklem, normal dağılım göstermediğinden parametrik olmayan ki-kare bağımsızlık testleri yapılmıştır. Önceki çalışmalardan da yararlanılarak risk davranışını tespit etmek, yaş, tecrübe, gelir, eğitim, işletme büyüklügü̈, daha önce karşılaşılan risklere bağlı olarak tarım sigortası yapılması ile aralarında bir ilişkinin bulunup bulunmadığı hipotezleri ki-kare bağımsızlık testi kullanılarak sınanmaya çalışılmıştır. Ayrıca, üstlenilen riskleri en aza indirmek için önerilen yöntemlerin (vadeli işlem, sigorta, garanti fiyat, kredi kullanma, pirim desteği, hedging) işlevselliği ve bilinirliği araştırılmıştır.

\section{Araştırma Bulguları ve Tartışma}

Anketlerden elde edilen verilere bağlı olarak, bölgede genel yapıyı bitkisel üretim yapan işletmeler oluşturmaktadır. Bölgede üretilen bitkisel ürünlerde pamuk, mısır ve buğday hâkim unsurdur. Böylelikle üreticiler farklı ürün deseni yerine tek tip ürünlere yer vermekle risk yönetim stratejilerini kullanmadığı kanısını oluşturmaktadır.

İşletmelerin sosyo- ekonomik durumu incelendiğinde; erkek çiftçilerin üreticilerin neredeyse tamamını oluşturdukları, yöredeki örf ve adetlerin etkisiyle kadınların ise ikinci planda kaldığı, genellikle çocuk doğurmak, tarlada çalışmak ve ev işleriyle uğraşmaktan ibaret kaldığı gözlemlenmiştir. Keza, ortalama çocuk sayısı 6.19 olup, TÜik verilerine göre bu rakam 2.1 çocuk olan Türkiye ortalamasının oldukça üzerindedir (TÜiK, 2017).

Tek kadın üretici 24 yaşında olup, Çiftçilerin \% 38'i 41-60 yaş aralığındadır. Üreticilerin yaş ortalaması ise 42 olarak hesaplanmıştır (Çizelge 1).

Çizelge 1. Cinsiyet ve yaş

Table 1. Gender and age

\begin{tabular}{lcccccc}
\hline \multirow{2}{*}{$\begin{array}{l}\text { Yaş } \\
\text { Age }\end{array}$} & \multicolumn{3}{c}{$\begin{array}{c}\text { Cinsiyet } \\
\text { Gender }\end{array}$} & \multicolumn{3}{c}{$\begin{array}{c}\text { Toplam } \\
\text { Total }\end{array}$} \\
\cline { 2 - 7 } & $\begin{array}{c}\text { Kadın } \\
\text { Female }\end{array}$ & $\%$ & $\begin{array}{c}\text { Erkek } \\
\text { Male }\end{array}$ & $\%$ & $\begin{array}{c}\text { Çiftçi Sayısı } \\
\text { Number of Farmers }\end{array}$ & $\%$ \\
\hline $18-25$ & 1 & 0.6 & 24 & 17.1 & 25 & 17.7 \\
$26-40$ & - & - & 44 & 31.4 & 44 & 31.4 \\
$41-60$ & - & - & 53 & 38.0 & 53 & 38.0 \\
61 ve üzeri & - & - & 18 & 12.9 & 18 & 12.9 \\
\hline Toplam & 1 & 0.6 & 139 & 99.4 & 140 & 100.0 \\
Total & & & &
\end{tabular}

Üreticilerin yaşı ile yeniliklere uyum sağlamaları arasındaki nedenselliği belirlemek için yapılan çalışmalarda farklı bulgular elde edilmiştir. 228 araştırmanın yaklaşık olarak yarısı bu konuda hiçbir ilişki bulunmadığını ortaya koyarken, \% 
20'si erken benimseyenlerin daha genç olduklarını, \% $30^{\prime} \mathrm{u}$ ise erken benimseyenlerin daha yaşlı olduklarını göstermiştir (Yavuz, 2010). Çizelge 2'de görüldüğü üzere bu araştırmada; üreticilerin yaşları ile tarımsal sigortayı benimsemeleri arasında istatistiki olarak bir ilişki bulunmamaktadır ( $p>0.05)$.

Çizelge 2. Yaş ile sigorta yapma arasındaki ilişki

Table 2. The relationship between the age and taking out insurance

\begin{tabular}{|c|c|c|c|}
\hline & $\begin{array}{c}\text { Value } \\
\text { (Değer) }\end{array}$ & $\begin{array}{l}\text { Degrees of Freedom } \\
\text { (Serbestlik Derecesi) }\end{array}$ & $\begin{array}{l}\text { 2-sided Asymptotic } \\
\text { Significance (Çift Yönlü } \\
\text { Asimptotik Önem) }\end{array}$ \\
\hline $\begin{array}{l}\text { Pearson Chi-Square } \\
\text { Pearson Ki-Kare }\end{array}$ & $1.999^{\mathrm{a}}$ & 3 & .573 \\
\hline $\begin{array}{l}\text { Likelihood Ratio } \\
\text { Olasılık Oranı }\end{array}$ & 1.822 & 3 & .610 \\
\hline $\begin{array}{l}\text { Linear-by-Linear Association } \\
\text { Doğrusal Bağlantı }\end{array}$ & 1.365 & 1 & .243 \\
\hline $\begin{array}{l}\text { Number of Valid Cases } \\
\text { Geçerli Durum Sayısı }\end{array}$ & 140 & & \\
\hline
\end{tabular}

Üreticilerin \% 14.3'ünün (20 kişi) bekar, geri kalan \% 85.7'sinin (120 kişi) ise evli olduğu tespit edilmiştir (Çizelge 3). Evli olanların bekâr olanlara göre daha fazla sigorta yaptırma eğiliminde olduğu belirlenmiştir. Üreticilerin medeni halleri ile sigorta yaptırmaları arasında istatistiki açıdan bir ilişki tespit edilmiştir $(p<0.05)$.

Çizelge 3. Medeni hal

Table 3. Maritual status

\begin{tabular}{lcc}
\hline $\begin{array}{l}\text { Medeni Hal } \\
\text { Maritual status }\end{array}$ & $\begin{array}{c}\text { Kişi } \\
\text { Number }\end{array}$ & $\%$ \\
\hline $\begin{array}{l}\text { Bekar } \\
\text { Single } \\
\text { Evli } \\
\text { Married }\end{array}$ & 20 & 14.3 \\
$\begin{array}{l}\text { Toplam } \\
\text { Total }\end{array}$ & 120 & 85.7 \\
\hline
\end{tabular}

Üreticilerin çoğunluğu olan \% 78.6'sı (110 kişi) ilkokul mezunudur. Üreticilerin \% 7.1'i (10 kişi) okur yazar olmayıp,
\% 7.9'u (11 kişi) ise lise mezunudur (Çizelge 4).

Çizelge 4. Eğitim düzeyi

Table 4. Education level

\begin{tabular}{lcc}
\hline $\begin{array}{l}\text { Eğitim Düzeyi } \\
\text { Education level }\end{array}$ & $\begin{array}{c}\text { Sayı } \\
\text { Number }\end{array}$ & $\%$ \\
\hline $\begin{array}{l}\text { Okuryazar değil } \\
\text { Illiterate } \\
\text { Illkokul } \\
\text { Primary } \\
\text { Lise }\end{array}$ & 10 & 7.1 \\
$\begin{array}{l}\text { High school } \\
\text { Lisans } \\
\text { Undergraduate } \\
\text { Lisansüstü } \\
\text { Graduate }\end{array}$ & 110 & 78.6 \\
\hline $\begin{array}{l}\text { Toplam } \\
\text { Total }\end{array}$ & 6 & 7.9 \\
\hline
\end{tabular}

Üreticiler arasında lisans ve lisansüstü eğitimini tamamlayan bireylerde bulunmaktadır. Üreticilerin \% $4.3^{\prime}$ ü (6 kişi) 
lisans, \% 2.1'i (3 kişi) ise lisansüstü eğitim düzeyine sahiptir (Çizelge 4). Üreticilerin eğitim düzeyi ile sigorta yaptırmaları arasında istatistiki açıdan bir ilişki tespit edilmiştir $(p<0.05)$.

Yenilikleri benimsemede eğitimin oynadığı rol farklı çalışmalarla tespit edilmiş olup, 275 çalışmanın 203 tanesinde, tarım alanında yenilikleri davranış biçimine dönüştürmeyle eğitim seviyesi arasında koşut bağlantı olduğu sonucuna ulaşılmıştır (Yavuz, 2010). Aynı şekilde, bu çalışmada eğitim düzeyi arttıkça, sigorta yaptırma istekliliğinin de arttığı bulgusuna rastlanılmıştır.

Ovada eğitim düzeyinin arttırılması ve üreticinin bilinçlendirilmesi hem toprağı verimli kullanmayı hem de sigorta gü- vencesi altında üretim faaliyetlerinde bulunma seviyesini arttıracağı beklenebilir.

Üreticiler ortalama 20 yıl mesleki tecrübeye sahiptir. Mesleki tecrübenin artması, riskleri azaltma yöntemleri konusunda etkili olabileceği düşünülmektedir. Uzun yıllar boyunca tarımsal üretimde bulunan üreticilerin, sık sık karşılaştıkları tarımsal risklere karşı sigorta sistemine dâhil olmak istemeleri, önceki çalışmalarda da elde edilen bir bulgudur. Çizelge $5^{\prime}$ de görüldüğg̈ üzere bu çalışmada mesleki deneyim ile sigorta yaptırma arasında istatistiki açıdan bir ilişkinin olmadığı tespit edilmiştir ( $p>0.05)$.

Çizelge 5. Mesleki deneyim süresi ile sigorta yapma arasındaki ilişki

Table 5. Relationship between professional experience and taking out insurance

\begin{tabular}{lccc}
\hline & $\begin{array}{c}\text { Value } \\
\text { (Değer) }\end{array}$ & $\begin{array}{c}\text { Degrees of Freedom } \\
\text { (Serbestlik Derecesi) }\end{array}$ & $\begin{array}{l}\text { 2-sided Asymptotic } \\
\text { Significance (Çift Yönlü } \\
\text { Asimptotik Önem) }\end{array}$ \\
\hline $\begin{array}{l}\text { Pearson Chi-Square } \\
\text { Pearson Ki-Kare }\end{array}$ & $.342^{\mathrm{a}}$ & 3 & .952 \\
$\begin{array}{l}\text { Likelihood Ratio } \\
\text { Olasılık Oranı } \\
\begin{array}{l}\text { Linear-by-Linear Association } \\
\text { Doğrusal Bağlantı }\end{array}\end{array}$ & .329 & 3 & .955 \\
$\begin{array}{l}\text { Number of Valid Cases } \\
\text { Geçerli Durum Sayısı }\end{array}$ & .147 & 1 & .702 \\
\hline
\end{tabular}

a. 2 cells ( $25.0 \%)$ have expected count less than 5 . The minimum expected count is 1.95

Üreticilerin \% 54.3'ü (76 kişi) 20 bin ve altında yıllık gelire sahiptir (Çizelge 6). Sulu koşullarda üretim yapan çiftçilerin ortalama gelirinin yaklaşık $37000 \mathrm{TL}$ olduğu hesaplanmıştır.

Üreticilerin gelir düzeyleri ile sigorta yaptırmaları arasında istatistiki açıdan bir ilişki bulunmaktadır ( $p<0.05)$.
Çizelge 6. Gelir düzeyi

Table 6. Level of income

\begin{tabular}{lcc}
\hline $\begin{array}{l}\text { Gelir Düzeyi } \\
\text { Level of income }\end{array}$ & $\begin{array}{c}\text { Sayı } \\
\text { Number }\end{array}$ & $\%$ \\
\hline $0-20000$ & 76 & 54.3 \\
$21000-50000$ & 42 & 30.0 \\
$51000-100000$ & 15 & 10.7 \\
$101000-150000$ & 2 & 1.4 \\
151000 ve üzeri & 5 & 3.6 \\
\hline Toplam & 140 & 100.0 \\
Total &
\end{tabular}


Ovada sahip oldukları arazi genişliği 51 ile 100 dekar arasında olan çiftçilerin oranı \% 40 (56 kişi) düzeyindedir (Çizelge 7). Türkiye'de tarımsal işletmelerin \% 78.9'u 100 dekardan küçük işletme büyüklük gruplarında yer almaktadır. Araştırma alanında işletme büyüklüğü ortalama; 144.93 dekardır. TÜik'in hazırlamış olduğu bültende Türkiye ortalamasının 60 dekar olduğu belirtilmiştir (TüiK, 2008).

Çizelge 7. Arazi genişliği

Table 7. Size of farm

\begin{tabular}{lcc}
\hline $\begin{array}{l}\text { Dekar } \\
\text { Decare }\end{array}$ & $\begin{array}{c}\text { Sayı } \\
\text { Number }\end{array}$ & $\%$ \\
\hline $1-20$ & 11 & 7.8 \\
$21-50$ & 26 & 18.6 \\
$51-100$ & 56 & 40.0 \\
$101-150$ & 15 & 10.7 \\
151 ve üzeri & 32 & 22.9 \\
\hline Toplam & 140 & 100.0 \\
Total & & \\
\hline
\end{tabular}

İ̧̧letme büyüklüğü arttıkça sigorta yaptırma eğilimi de artacağı beklenmektedir. Çünkü sigorta yaptırmanın getireceği maliyete ancak arazi genişliği yüksek olan işletmelerde katlanılması beklenen bir durumdur. Ancak bu çalışmada üreticilerin sahip oldukları arazi genişliği ile sigorta yaptırmaları arasında istatistiki açıdan bir ilişki tespit edilememiştir ( $p>0.05$ ).

Arazi mülkiyetinin dağınık olması, gelir dağılımında da adaletsizlik sonucunu kaçınılmaz olarak doğurmaktadır. Bu nedenle; ülkemizde mevcut bulunan gelir dağılımı adaletsizliğinin çarpıcı bir biçimi ovada da gözlenmektedir. Arazi büyüklüğü küçük olan ya da hiç olmayan üreticilerin başka illerde mevsimlik tarım işçisi olarak çalışmaları bunun kanıtı olarak sayılabilir. Ovada yaklaşık 250000 kişi, yani Şanlıurfa nüfusunun önemsenecek boyutta bir kesiminin, dışarı illere çalışmak için gitmesi; eğitim başta olmak üzere birçok sorunu da beraberinde getirmektedir.

Üreticilerin \% 81.4'ü sosyal güvencelerinin olduğunu belirtmişlerdir. Hâlbuki bu rakamın gerçek bir sosyal güvence olmayan "Yeşil Kart" olduğu anketlerden elde edilen verilerden açıkça görülmektedir. Şans oyunlarını hiç oynamıyorum diyenlerin oranı \% 90'dır.

$\mathrm{Bu}$ sonuç kırsal kesimin kaderci bir anlayışa sahip olduğunun bir göstergesi sayılabilir. Şans oyunları oynayıp oynamama durumu üreticinin risk alma isteği ölçülmeye çalışılmış ancak bu bölgeye özgü sosyal, kültürel ve dinsel tutumların etkisi ile sonuç hiçbir zaman oynamama tercihine yoğunlaşmıştır.

Çizelge 8. Sigorta yaptırma durumu

Table 8. Status of taking out insurance

\begin{tabular}{lcc}
\hline $\begin{array}{l}\text { Durum } \\
\text { Status }\end{array}$ & $\begin{array}{c}\text { Sayı } \\
\text { Number }\end{array}$ & $\%$ \\
\hline $\begin{array}{l}\text { Evet } \\
\text { Yes } \\
\text { Hayır } \\
\text { No } \\
\text { Hiç duymadım }\end{array}$ & 21 & 15.0 \\
$\begin{array}{l}\text { Never heard } \\
\text { Toplam }\end{array}$ & 114 & 81.4 \\
Total & 5 & 3.6 \\
\hline
\end{tabular}

Üreticilerin \% 81.4'ü tarımsal sigorta yaptırmamıştır. Keza tarım sigortasını hiç duymadım diyenlerin oranı ise \% 3.6'dır. Üreticilerin sadece \% 15'i tarımsal sigorta yaptırmıştır. Bu oran daha önce tarım 
sigortası yaptıranlarla aynı özelliği taşımaktadır (Çizelge 8).

Çalışmada elde edilen sigorta yapmama ile ilgili bulgular; önceki çalışmaların bulgularıyla örtüşmektedir. Mevcut durumda; ulusal ekonomide özellikle kırsal alanlarda tasarruf kıtlığı, tatmin edici gelir seviyesinin düşüklüğü ve kaderci bakış açısının egemen olması, sigorta talebinin geri planda kalmasına yol açtığı, araştırmacılar tarafından önceki çalışmalarda da tespit edilmiştir. Nitekim üreticilerin tarım sigortaları konusunda yeterince bilgi sahibi olmadıkları ve sigortanın karşılaştıkları zararları gidereceği yönündeki güvensizliklerinin olduğu; çeşitli bölgelerde tarım sigortaları ile ilgili yapılan alan çalışmalarıyla belirlemiştir (Akçaöz ve ark., 2001; Akdemir ve ark., 2001; Karahan, 2005).

Üreticilerle yapılan görüşmeler sonucunda üreticiler en çok karşılaştıkları risklerin; hastalık ve zararlılar, iklim koşulları, fiyatların istikrarsız oluşları ve tohum/gübre kalitesi olduğu tespit edilmiştir. Amasya ilinde yaygın olarak yetiştirilen ürünlerde verim ve fiyat riski isimli çalışmada; üreticinin geleceğe yönelik yapacağı yatırım ve vereceği kararlarda karşılaştığı dalgalanmalar içerisinde verim, fiyat ve gelirdeki dalgalanmalar en önemlileri olduğu bulgusuna rastlanmıştır (Çetin ve Esengün, 2015). Yine Akçaöz ve ark. (2006), Antalya ilinde üretimde risk yönetimi ve tarım sigortası uygulamaları adlı çalışmalarında; üreticilerin doğal riskler ve gelir azalmasına yol açan fiyat riski ile karşılaştıkları belirlenmiştir. Bu çalışmada ise, doğal risklerin yani iklim koşulları ve fiyat riski ile üreticilerin yüz yüze gelmesi bulgusu, bu konuda yapılan önceki çalışmaların bulgularıyla örtüştüğü gözlemlenmiştir. İkikat ve ark. (2010) çalışmalarında; Erzurum yöresinde tarımsal üretim üzerinde en etkili üç unsurun sırasıyla yağmurun gereğinden az olması, don olayının görülmesi ve girdi (gübre, ilaç gibi) maliyetlerindeki değişmeler olarak sıralamışlardır. İklim koşulları ve girdi maliyetleri etkili risk faktörleri olarak literatürde yerini almıştır.

$\mathrm{Bu}$ çalışmada elde edilen verilerden yola çıkarak; eğitim düzeyi $(P<0.05)$, medeni hal $(P<0.05)$, önceleri sigorta yaptırma durumu $(P<0.05)$, kredi kullanma durumu $(P<0.05)$, gelir düzeyi $(P<0.05)$ ve prim desteği $(P<0.05)$ gibi değişkenler ile tarımsal sigorta yaptırma arasında ki-kare bağımsızlık testine dayanarak istatistiki açıdan bir ilişki bulunmuştur. Ayrıca sigorta yaptırmama nedenleri arasında; primlerin yüksek olması, alışkanlık olmaması, zararların karşılanmama endişesi, gelir yetersizliği ve üreticilerin sigorta hakkında yeterli bilgi sahibi olmaması sıralanabilir.

\section{Sonuç ve Öneriler}

Tarım ülke ekonomileri için yaşamsal bir üretim sektörüdür. İnsanoğlu yaratılışından beri gerek yiyeceği gerekse giyeceği bakımından doğaya, dolayısıyla toprağa bağımlıdır. Insanlık tarihi seyir içerisinde doğayla mücadele etme biçiminde 
ayakta durabilmiştir. Tarımsal çıktı elde etme amaciyla faaliyette bulunan üreticiler her zaman belirli güçlüklerle karşılaşmışlardır. Nüfusun artışı ve kullanılabilir toprak miktarının azalması ile birlikte, yeterli beslenme kaygısı artmış, bunun neticesinde birim alandan daha fazla ürün elde etme arayışı ve çabası sürekli gündemde kalmıştır. Birim alandan daha fazla ürün elde etmek tarımsal üretimin sık sık karşılaştığı risklerin en aza indirilmesi ile mümkündür. Bu bağlamda gerek ulusal gerekse uluslararası alanda konu ile ilgili birçok çalışma yapma ihtiyacı doğmuştur.

$\mathrm{Bu}$ çalışmada; Harran Ovası'nda üretim faaliyetlerinde bulunan çiftçilerin yüz yüze geldikleri riskler ve riskleri en aza indirmek için tercih ettikleri yollar tespit edilmeye çalışılmıştır. Ovanın sulamaya açılmasıyla birlikte yoğun girdi kullanımı nedeniyle, çeşitli hastalık ve zararlılar ile yüz yüze gelen 140 üretici ile görüşülmüştür. Eğitim ve gelir seviyesi düşük muhafazakâr anlayışa sahip tarımsal üreticilerin risk algıları da farklı olmaktadır. Bu durum, riskleri algılayış biçimini etkilemekte ve risklerin bertaraf edilmesinde etkili yöntemler ve araçlar kullanma isteğini azaltmaktadır. Eğitim düzeyi, medeni hal, önceleri sigorta yaptırma durumu, kredi kullanma durumu, gelir ve prim desteği gibi değişkenler ile tarımsal sigortası yaptırma arasında istatistiki açıdan ilişki bulunmuştur. Ayrıca sigorta yaptırmama nedenleri arasında primlerin yüksek olması, alışkanlık olmaması, zararların karşılanmama endişesi, gelir yetersizliği ve üreticilerin sigorta hakkında yeterli bilgi sahibi olmaması sıralanabilir.

$\mathrm{Bu}$ konu ile ilgili çalışmaların bölgesel nitelikli olması ve farklı ürünlerde farklı risk faktörlerinin olması sonuçlarında farklı çıkmasına neden olmaktadır. Nitekim saha çalışmasından elde edilen verilere göre; fiyat dalgalanmaları yani sık sık fiyatların değişmesi hatta bazı mevsimler aşırı düşüklüğü, üreticiyi zor durumda bırakmaktadır. Örneğin 2013 yılı pamuk üretim sezonunda 2 TL'ye yaklaşmış bulunan pamuk fiyatı, 2014 yılı sezonunda 1 TL'ye kadar gerilemiştir. 2016 yılında ise tekrar 2TL civarlarına yükselmiştir. Mısır üretiminde ise ithalata dayalı yoğun girdi kullanımı üretici için fazladan maliyet getirmektedir.

Üreticilerin bu şekilde karşılaştıkları riskleri en aza indirmek için tarım sigortası önerilmektedir. Ayrıca vadeli işlemler, sözleşmeli tarım, münavebeli ekim vb. uygulamalarda gündemdeki yerini almıştır. Buna bağlı olarak, bölgede ÇUKOBIRLiK gibi üreticilerin kuracağı kooperatifler, çiftçinin serbest piyasanın acımasız insafına terk edilmesini önleyebilecektir. Devletin sigorta prim desteğini arttırması da bir diğer çözüm yolu olabilecektir. Sigorta primlerinin yüksek oluşu ve destekleme oranı, piyasa fiyatları göz önünde bulundurularak yeniden değerlendirilebilir. Tarım sigortalarının uygulamalarında bölgenin sosyo-kültürel ve toplumsal yapisına uygun yeni politikaların geliştirilmesi ve yayım çaışmalarının arttırılması gerekmektedir. 


\section{Kaynaklar}

Akçaöz, H., Özkan, B., Karadeniz, F.C., Fert, C., 2006. Tarımsal Üretimde Risk Kaynakları ve Risk Stratejileri: Antalya ili Örneği. Akdeniz Üniversitesi Ziraat Fakültesi Dergisi, 19 (1): 89-97.

Akdemir, Ş., Binici, T., Şengül, H., Akçaöz, H., Karlı, B., Aktaş E., Gizir, M., 2001. Bölge Bazlı Tarım Sigortasının Türkiye'de Seçilmiş Bölgeler İçin Potansiyel Sigorta Talebinin ve Talebin Karşılanabilirliğinin Belirlenmesi. Proje Raporu 2001, 11. Tarımsal Ekonomi Araştırma Enstitüsü, Ankara, 93s.

Aydogdu, M.H., Yenigun, K., 2016. Farmers' Risk Perception towards Climate Change: A Case of the GAP-Şanlıurfa Region, Turkey. Sustainability, 8 doi:10.3390/su8080806

Aydogdu, M. H., 2016. Farmers' Risk Perception And Willingness to Pay for Environment: Case Study of GAP-Sanliurfa, Turkey. Fresenius Enviromental Bulletin, 25 (12): 5449-5455.

Bergfjord, O.J., 2013. Farming and Risk Attitude. Emirates Journal of Food Agriculture, 25 (7): 555-561.

Çetin, İ., Esengün, K., 2012. Amasya İlinde Kuru Soğan Yetiştiren İşletmelerin Risk Davranışına Göre Sosyo-Ekonomik Analizi. GOÜ Ziraat Fakültesi Dergisi, 29 (1): 81-92.

Çetin, I.., Esengün, K., 2013. Amasya İlinde Yaygın Olarak Yetiştirilen Ürünlerde Verim ve Fiyat Riski. KMÜ Sosyal ve Ekonomik Araştırmalar Dergisi, 15 (25): 57-65.

İkikat, T.E., Birinci, A., Miran, B., 2010. Çiftçilerin Sel ve Kuraklık Sigortası Yaptırma İsteğini Etkileyen Faktörlerin Analizi: TRA-I Bölgesi Örneği. IX. Tarım Ekonomisi Kongresi, 2224 Eylül, Şanlıurfa, 199-205s.

İkikat, T.E., Birinci, A., 2013. TRA I Bölgesindeki Çiftçilerin Riske Karşı Tutumları Açısından Sosyo-Ekonomik Özellikleri. Gaziosmanpaşa Bilimsel Araştırma Dergisi, 7 (2): 55-66.

İnan, i. H., 2016. Tarım Ekonomisi ve İşletmeciliği. İdeal Kültür Yayınları, İstanbul, 404s.

İpekçioğlu, Ş., Işgın, T., Monis, T., Saner, G., Bilgiç, A., 2010. Güneydoğu Anadolu Bölgesi'nde Devlet Destekli Bitkisel Ürün Sigortası
Yaptırma İstekliliğinin Belirlenmesi. IX. Tarım Ekonomisi Kongresi, 22-24 Eylül, Şanlıurfa, 259-265s.

Karahan, Ö., 2005. Tarımda Üreticilerin Risk Karşısındaki Davranışları: Ege Bölgesinden Bir Örnek Olay. Ege Üniversitesi Ziraat Fakültesi Dergisi., 42 (3): 147-158.

Keskinkılıç, K., Alemdar, T., 2013. Tarım Sigortacılığı; Dünya ve Türkiye'deki Uygulamaların Değerlendirilmesi. Çukurova Üniversitesi Fen ve Mühendislik Dergisi, 29 (3): 114-123.

Kızılboğa, R., 2012. Risk Yönetimi ve Ülke Uygulamalarında Risk Yönetim Modelleri. Akademik Araştırmalar ve Çalışmalar Dergisi, 4 (7): 82-99.

Kopali, A., Doko, A., 2014. Analysis Precipitation Regime: Period Dryness and Climate Risk Determination for Agriculture on Albanian Territory. Albanian Journal of Agricultural Sciences, Special Edition, Tirana: 159-163.

Özcan, M., 2012. Tarımsal İşletmelerde Risk Yönetimi ve Bir Alan Çalışması. Yüksek Lisans Tezi. Atılım Üniversitesi, Sosyal Bilimler Enstitüsü, Ankara.

Pennings, M.E., Garcia, P., 2001. Measuring Producers' Risk Preferences: A Global RiskAttitude Construct. American Journal of Agricultural Economics, 83 (4): 993-1009.

Şahin, A., Miran, B., 2007. Çiftçi Algılarına Göre Bitkisel Ürünlerin Risk Haritası: Bayındır İlçesi Örneği. Ege Üniversitesi Ziraat Fakültesi Dergisi, 44 (3): 59-74.

Şahin, A., Cankurt, M., Günden, C., Miran B., 2008. Çiftçilerin Risk Davranışları: Bir Yapısal Eşitlik Modeli Uygulaması. Dokuz Eylül Üniversitesi iktisadi ve idari Bilimler Fakültesi Dergisi, 23 (2): 153-172.

TÜik, 2008. Tarımsal İşletme Yapı Araştırması 2006. TÜik Haber Bülteni 17 Aralık 2008, Sayı 196.

TÜik, 2017. Doğum İstatistikleri 2016. TÜiK Haber Bülteni 18 Mayıs 2017, Sayı 24647.

Yavuz, G.G., 2010. Polatlı İlçesinde Üreticilerin Tarım Sigortası Yaptırmaya Karar Verme Sürecinde Etkili Olan Faktörlerin Analizi. Doktora Tezi, Ankara Üniversitesi Fen Bilimleri Enstitüsü, Ankara, 159s.

Yamane, T. 2010. Temel Örnekleme Yöntemleri, Literatür Yayınları, 528s. 